\title{
Secular Trends in a Population with Ischemic Heart Disease Admitted to the Instituto do Coração in São Paulo
}

\author{
Bruno Caramelli, Luciana Savoy Fornari, Maristela Monachini, Dália Ballas, Nilson Roberto Fachini, \\ Antônio de Pádua Mansur, José Antônio Franchini Ramires \\ São Paulo, SP - Brazil
}

\begin{abstract}
Objective - To assess the clinical and demographic characteristics of a population with ischemic heart disease admitted in the final decades of the 20th century.

Methods - This study retrospectively assessed patients hospitalized with ischemic heart disease divided into the following 2 groups: acute group - 11.181 patients with acute myocardial infarction admitted from 1/1/82 to 12/31/94; and chronic group - 4.166 patients undergoing coronary artery bypass graft surgery from 1/1/84 to 12/31/94.
\end{abstract}

Results - In the acute group, an increase in the percentage of females (from $22.7 \%$ to $27.7 \%, P<0.001$ ) and diabetic individuals (from $12.4 \%$ to $17.5 \%, P<0.001$ ) was observed, as was an increase in age (from $57.4 \pm 11.5$ to $59.9 \pm 12.1$ years, $P<0.05)$. In-hospital mortality was greater among females $(27.8 \%$ and $15.7 \%, P=0.001)$, among diabetic individuals $(24.2 \%$ and $17.8 \%, P=0.001)$, and among the elderly $(60.9 \pm 15.2$ and $57.7 \pm 11.8$ years, $P=0.0001)$. In the chronic group, an increase in the percentage offemales (from $17.5 \%$ to $27.2 \%, P=0.001$ ) was observed, as was an increase in age (from $56.3 \pm 8.6$ to $60.5 \pm 9.6$ years, $P=0.0001)$. In-hospital mortality was greater among females $(8.3 \%$ and $5.8 \%, P<0.05)$ and among the elderly (58.1 19.1 and $62.1 \pm 7.9$ years, $P=0.0001$ ).

Conclusion - The characteristics of the population studied with ischemic heart disease point towards a worse prognosis, due to the greater percentages offemales, older patients, and diabetic patients, groups known to have greater in-hospital mortality.

Keywords: ischemic heart disease, acute myocardial infarction, coronary artery bypass graft surgery

InInstituto do Coração do Hospital das Clínicas - FMUSP

Mailing address: Bruno Caramelli - InCor - Av. Dr. Eneas C. Aguiar, 44

Cep 05403-000 - São Paulo, SP, Brazil - E-mail: bcaramel@incor.usp.br English version by Stela Maris C. e Gandour
The 20th century witnessed profound changes in medicine. The evolution of knowledge, new techniques, and scientific methodology has established that treatment be based on the results of research, which elucidates the mechanisms of disease and assesses the results of proposed therapies. This concept, called evidence-based medicine, is currently the starting point of medical teaching and scientific research ${ }^{1}$.

In the final decades of the 20th century, mechanisms of transmission and development of diseases were discovered, as well as their diagnoses, treatment, and prevention. Some diseases have disappeared or their importance has been significantly reduced with the advent of vaccines and appropriate treatment. All these factors have contributed to the aging of the population and the increase in the incidence of diseases of the elderly, a process called epidemiological transition ${ }^{2}$. The increase in the incidence of cardiovascular diseases and mortality consequent to them in the final decades is a more recent example of an epidemiological transition ${ }^{3}$, causing a change in the characteristics of the ill population and requiring mechanisms of response by health care professionals.

Recently, some studies have shown a reduction in the incidence of mortality due to cardiovascular diseases ${ }^{4-6}$, as well as differences between the sexes, in the age groups, and in the treatment of cardiovascular diseases ${ }^{7-13}$.

Despite these changes, cardiovascular diseases have remained the first cause of death in most countries, Brazil included, reaching young people in their productive years and having a great economic impact ${ }^{14,15}$. The magnitude of the problem requires a multidisciplinary approach to the continuous search for information to better understand the natural history and appropriate selection of therapeutic strategies of primary and secondary prevention, because the characteristics of the population undergo permanent changes.

The objective of this study was to assess the clinical and demographic characteristics of the population with ischemic heart disease who were admitted to the Instituto do Coração (InCor) of the Medical School of the University of São Paulo in the final 2 decades of the 20th century. 


\section{Methods}

The present study retrospectively analyzed patients diagnosed with ischemic heart disease admitted to InCor with the acute and chronic forms of ischemic heart disease. Two groups of patients were defined as follows: acute comprising patients aged 20 years or older diagnosed with acute myocardial infarction and admitted to the hospital from $1 / 1 / 82$ to $12 / 31 / 94$. The criteria used for diagnosing myocardial infarction were the same as those used in the World Health Organization MONICA Project ${ }^{16}$; chronic comprising patients diagnosed with ischemic heart disease and undergoing coronary artery bypass graft surgery. Only patients older than 20 years and admitted to the hospital from $1 / 1 / 84$ to $12 / 31 / 94$ were studied, and the diagnosis of ischemic heart disease met the classical clinical and cine coronary angiographic criteria of the national and international literature ${ }^{17,18}$. In the latter group, the diagnosis of myocardial infarction was an exclusion criterion to prevent patients from being included in both groups.

In the acute group, the variables age, sex, and in-hospital mortality, and the presence of diabetes mellitus as an associated disease were analyzed. In the chronic group, the variables age, sex, and in-hospital mortality were analyzed. Information was retrospectively retrieved from the hospital databank. The medical records and statistics department of the hospital attributed a code to each diagnosis, according to the International Classification of Diseases (ICD-10) ${ }^{19}$. In the acute group, only the diagnosis of acute myocardial infarction was analyzed, and, in the chronic group, only coronary artery bypass graft surgery was analyzed, patients diagnosed with myocardial infarction being excluded.

In regard to the statistical analysis, the classifying variables (sex, in-hospital mortality, and presence of diabetes mellitus) were descriptively presented in tables containing the absolute and relative frequencies. An initial exploratory analysis allowed the division into time periods according to the years of changes in frequencies. Data for the acute group were analyzed divided into the following 3 periods: 1992-1995, 1986-1990, and 1991-1994; data for the chronic group were analyzed divided into the following 3 periods: 1984-1985, 1986-1990, and 1990-1994. The chi-square test was used to compare proportions, and when the test was significant, the analysis was continued with the partition of the chi-square to determine the differences between the periods. The continuous variable age was descriptively presented in tables containing means, standard deviations, and minimum and maximum values; the means were compared using analysis of variance and the Tukey test, a multiple comparison procedure ${ }^{20}$. The Student $t$ test was used to analyze the relation between the variable age and in-hospital mortality, and the chi-square test and its partition were used for the other variables. In univariate analysis, the variables with statistical significance in regard to in-hospital mortality were used for adjusting a multiple logistic regression model with the stepwise selection method ${ }^{20,21}$. The significance level adopted for this study was 0.05 .

\section{Results}

Data obtained in the 2 groups are shown separately.

Acute group - 11.181 patients were studied. The division of female patients into periods of relative frequency is shown in figure 1. No significant difference was observed between the periods $1982-1985$ and $1986-1990(\mathrm{P}=0.13)$. However, a significant increase in the frequency of females with myocardial infarction was observed from period 19861990 to period 1991-1994 $(\mathrm{P}<0.001)$.

A significant increase in the number of patients diagnosed with diabetes mellitus in association with myocardial infarction occurred, and the division into periods is shown in figure 2. No significant difference was observed between the periods $1982-1985$ and $1986-1990(\mathrm{P}=0.09)$. However, a significant increase in the frequency of patients diagnosed with the association of diabetes mellitus and myocardial infarction occurred from period 1986-1990 to period 1991-1994 $(\mathrm{P}=0.001)$.

A significant increase in the age of patients with myocardial infarction was observed in the periods analyzed. No significant difference between the periods 1982-1985 (57.4 years) and 1986-1990 (57.4 years) occurred. However, a significant increase in the age of patients with myocardial infarction was observed from the period 1986-1990 (57.4 years) to the period 1991-1994 (59.9 years, $\mathrm{P}<0.05$ ) (fig. 3).

The analysis of the relation between the variables age and sex revealed that females were older than males $(62.3 \pm 13$ and $57 \pm 12.1$ years, respectively, $\mathrm{P}=0.0001$ ).

Table I shows the variables age, sex, and presence or absence of diabetes in absolute and relative numbers regarding the 3 periods analyzed.

The relation between the variable in-hospital mortality

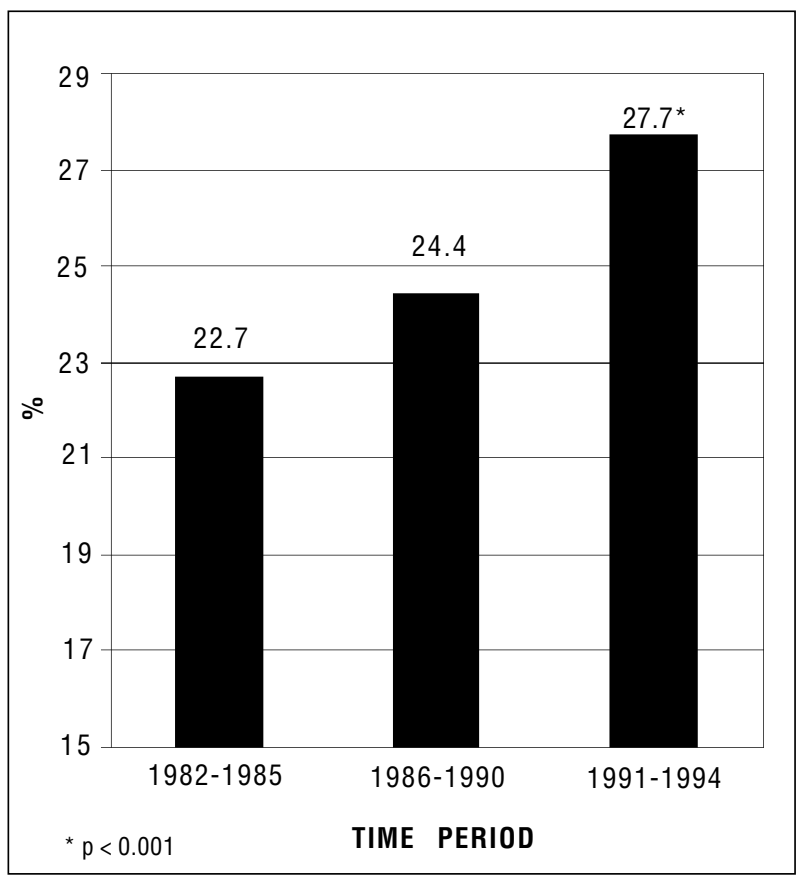

Fig. 1 - Division into time periods of the relative frequencies of the female patients in the acute group. 


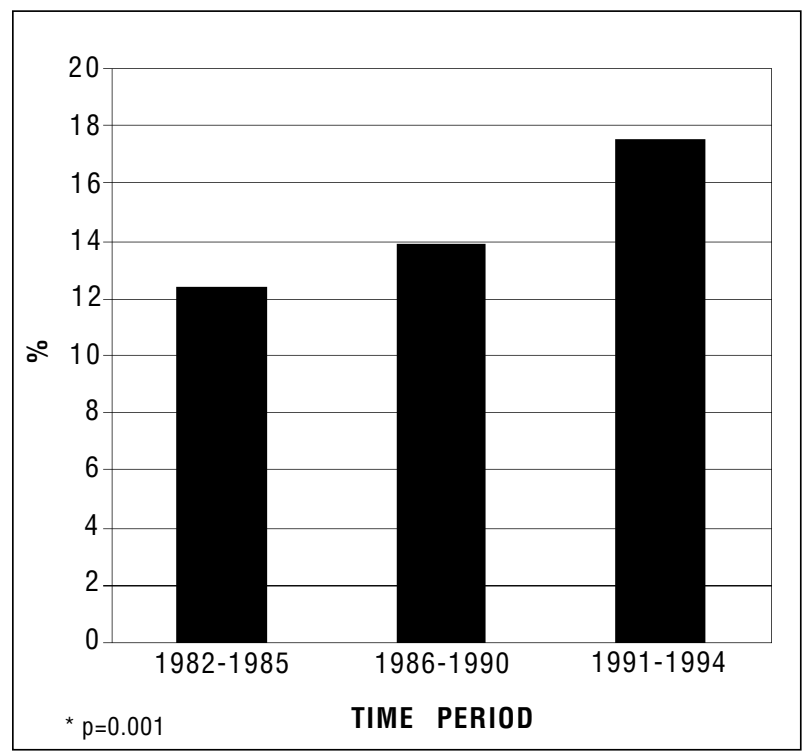

Fig. 2 - Division into time periods of the relative frequencies of the patients with diabetes mellitus as an associated diagnosis in the acute period.

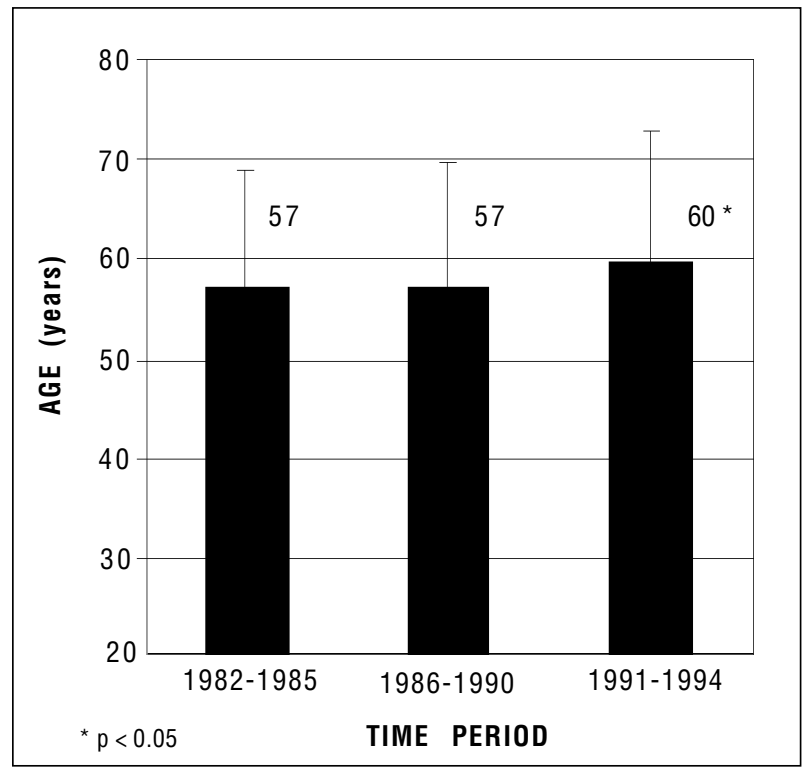

Fig. 3 - Age means and standard deviations in patients of the acute group divided into time periods.

and each of the other variables studied was analyzed. The univariate analysis revealed greater coefficients of in-hospital mortality due to myocardial infarction among females ( $27.8 \%$ vs $15.7 \%, \mathrm{P}=0.001$ ), older patients (mean age of 60.9 years in deceased patients versus 57.7 years in survivors, $\mathrm{P}=0.0001)$, and in patients with diabetes mellitus $(\mathrm{P}=0.001)$ (fig. 4). In the multiple logistic regression model, only the variables sex and age had statistical significance in regard to in-hospital mortality $(\mathrm{P}=0.0001$ for sex and $\mathrm{P}=0.0001$ for age, odds ratio of 0.528 and 1.016 , confidence intervals of 0.476 0.585 and $1.012-1.020$, respectively).

Chronic group -4.166 patients were studied and a significant increase in the number of females was observed with the division into periods shown in figure 5. No

\begin{tabular}{|lccc|}
\hline \multicolumn{4}{|c|}{ Table I - Division into time periods of the variables sex, age, and the } \\
presence of diabetes in the acute group \\
\hline Year & $1982-1985$ & $1986-1990$ & $1991-1994$ \\
\hline Female & $544(22.7 \%)$ & $1112(24.7 \%)$ & $1188(27.7 \%)$ \\
Male & $1851(77.3 \%)$ & $3389(75.3 \%)$ & $3097(72.3 \%)$ \\
Total & 2395 & 4501 & 4285 \\
With DM & $12.4 \%$ & $13.9 \%$ & $17.5 \%$ \\
No DM & $87.6 \%$ & $86.1 \%$ & $82.5 \%$ \\
Age & $57.4 \pm 11.5$ & $57.4 \pm 12.5$ & $59.9 \pm 13.1$ \\
& $(20-91)$ & $(20-93)$ & $(20-96)$ \\
\hline \multicolumn{4}{|}{} \\
\hline
\end{tabular}

significant difference was observed between the periods 1984-1985 and 1986-1990 $(\mathrm{P}=0.63)$. However, a significant increase was observed in the number of females in the chronic group from period 1986-1990 to period 1991-1994 $(\mathrm{P}=0.001)$.

In the chronic group patients, a significant increase in age was observed both from period 1984-1985 (56.3 years) to period 1986-1990 (58.4 years) and from period 1986-1990 to period 1991-1994 (60.5 years, $\mathrm{P}<0.05$ ) (fig. 6). Table II shows the variables age and sex in absolute and relative numbers in regard to the 3 periods analyzed.

Greater coefficients of in-hospital mortality were observed among females $(8.3 \%$ vs $5.8 \%, \mathrm{P}=0.007)$ and the elderly (mean age of 62.1 years in deceased patients versus 58.1 years in survivors, $\mathrm{P}=0.0001$ ). In the multiple logistic regression model, age was the only variable with statistical significance in regard to in-hospital mortality $(\mathrm{P}=0.0001$, odds ratio of 1.053, confidence interval of 1.038-1.069).

\section{Discussion}

This study revealed a significant increase in the age and number of females among the patients with the acute and chronic forms of ischemic heart disease. This study

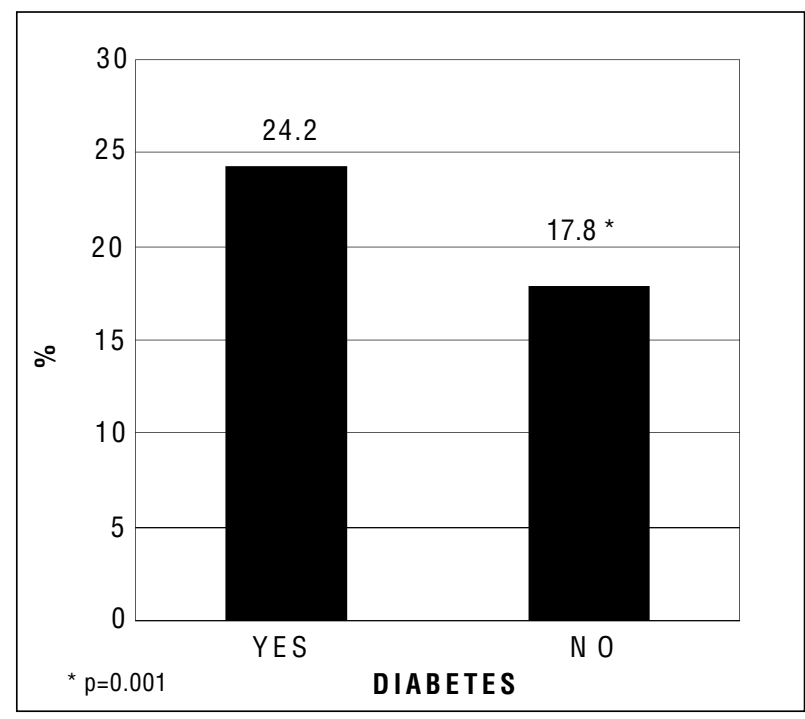

Fig. 4 - Distribution of the coefficients of in-hospital mortality according to the presence or absence of diabetes mellitus as an associated diagnosis in the acute group. 


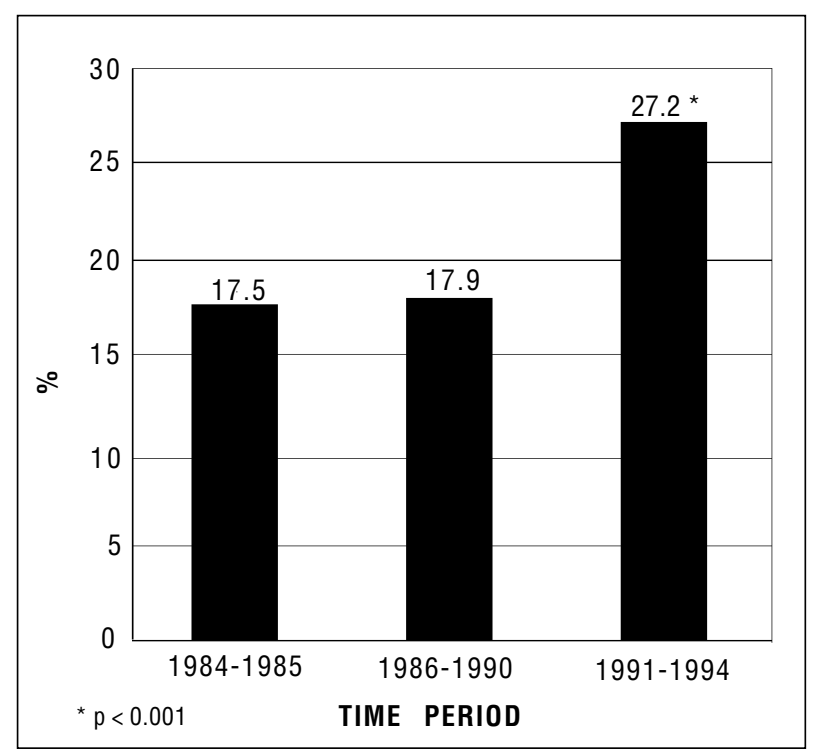

Fig. 5 - Division into time periods of the relative frequencies of the female sex in the chronic group.

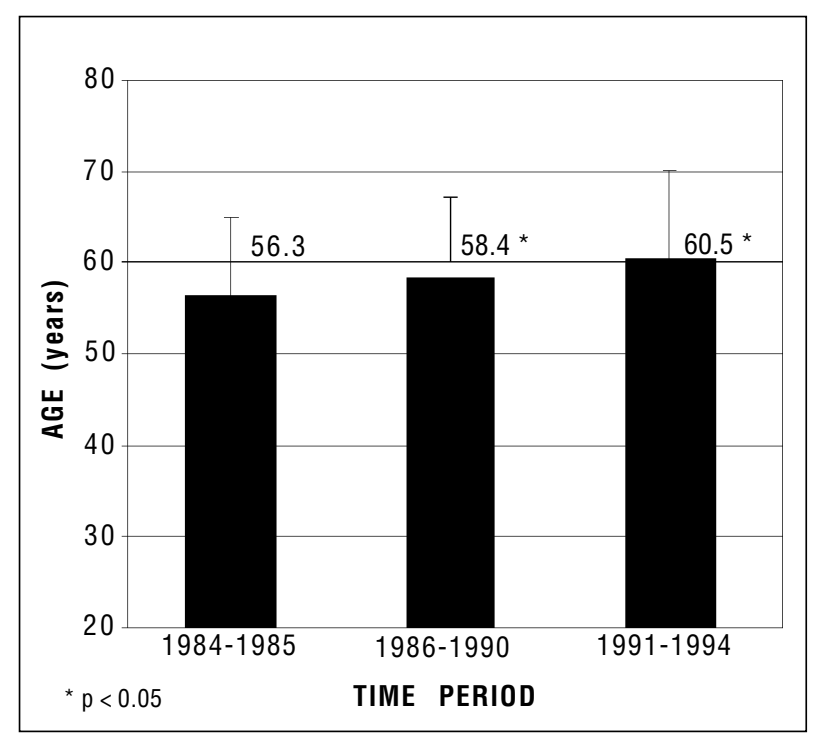

Fig. 6 - Age (in years) means and standard deviations in the chronic group divided into time periods.

also corroborated the findings of previous studies, in which females were older than males ${ }^{7,8,22}$.

The preoccupation with the changes in the characteristics of the population diagnosed with ischemic heart disease has been reported in the literature, and some of the studies are discussed below.

Naylor and Chen ${ }^{5}$, in a study with 110.979 patients to determine the tendencies of in-hospital mortality due to myocardial infarction, analyzed data from all general hospitals in Ontario, Canada, in the years 1981, 1983, 1985, 1987, 1989 , and 1991. The distribution of the patients according to sex and age revealed a variation in age over the decade. An increase in the number of patients with myocardial infarction in the age groups 70-79 and $>80$ years was observed (from

\begin{tabular}{|c|c|c|c|}
\hline \multicolumn{4}{|c|}{$\begin{array}{l}\text { Table II - Division into time periods of the variables sex, age, and the } \\
\text { presence of diabetes in the chronic group }\end{array}$} \\
\hline Year & 1984-1985 & 1986-1990 & 1991-1994 \\
\hline Female & $197(17.5 \%)$ & $369(17.9 \%)$ & $269(27.2 \%)$ \\
\hline Male & $925(82.4 \%)$ & $1687(82 \%)$ & $719(72.8 \%)$ \\
\hline Total & 1122 & 2056 & 988 \\
\hline Age & $\begin{array}{l}56.3 \pm 8.6 \\
(26-79)\end{array}$ & $\begin{array}{l}58.4 \pm 8.7 \\
(29-81)\end{array}$ & $\begin{array}{l}60.5 \pm 9.6 \\
(33-82)\end{array}$ \\
\hline
\end{tabular}

$25.1 \%$ to $28 \%$, and from $12.4 \%$ to $17.3 \%$, respectively). On the other hand, a decrease in the number of females with myocardial infarction in the age group 50-59 years was observed (from $22.1 \%$ to $16.7 \%$ ). During the same period, the percentage of females increased from $34.3 \%$ to $35.7 \%$. That multicenter study comprising the entire population of patients with myocardial infarction in a Canadian region has corroborated the findings in our population.

Similar results were reported by Diegues et a ${ }^{11}$ analyzing the population of patients with myocardial infarction admitted to the Instituto Dante Pazzanese of Cardiology in São Paulo in different periods from 1973 to 1996. The authors reported a progressive increase in the mean age of myocardial infarction presentation from 53.3 to 60 years and in the percentage of females from $10.7 \%$ to $29 \%$. No significant variation in the presence of diabetes mellitus as an associated disease in that population was observed.

In regard to the chronic form of ischemic heart disease, Pepine et al ${ }^{12}$ studied a population of 5.125 patients with chronic stable angina in 1990 and reported the predominance of females $(53 \%)$ with an elevated mean age greater than that of males ( 70.8 vs 67.2 years). In comparison with previous studies, the authors concluded that the characteristics of the population with chronic stable angina have been changing, and that, independent of the causes involved, that information is important for understanding the natural history of the disease and for selecting the appropriate diagnostic and therapeutic strategies.

No study about the secular trends of the characteristics of the population undergoing myocardial revascularization has been found in the literature. Although Pepine et al ${ }^{12}$ studied a different population and did not analyze other time periods, their study confirmed our findings in patients with the chronic form of ischemic heart disease undergoing that procedure.

Several studies have reported the occurrence of a reduction in the incidence of ischemic heart disease, and some authors have suggested that this reduction is smaller in the female sex ${ }^{3,23}$. This fact could account for the findings in this and other studies regarding the increase in the percentage of females with ischemic heart disease. The tendency towards a smaller reduction in smoking in the female sex as compared with that in the male sex (observed in the last Brazilian census) and the growing participation of females in the job market could relate to these data.

On the other hand, the aging of the population detected in the final decades and the consequent increase in the inci- 
dence of diseases of aging, known as epidemiological transition, is a continuous process and could explain in this population, as well as in other populations studied, the increase in the percentage of patients of more advanced age groups ${ }^{2-4}$.

Diegues et al ${ }^{11}$ reported no significant changes in the prevalence of diabetes mellitus in patients with myocardial infarction at the Instituto Dante Pazzanese of Cardiology in São Paulo from 1973 to 1996.

In a larger population, our study showed a significant increase in the incidence of diabetes in association with myocardial infarction during the period from 1982 to 1994. Changes in the age profile could contribute to the greater frequency of that association, because diabetes is the most prevalent disease in the older segments of the population ${ }^{12}$. This finding has important clinical implications, because the greater prevalence of diabetes as a comorbidity in ischemic heart disease is associated with a greater number of complications and a more prolonged hospitalization, which was observed in the acute group. In the latter group, the diagnosis of diabetes associated with myocardial infarction relates to higher in-hospital mortality rates.

A significant change in in-hospital mortality in the period studied was observed only in the acute group. However, no tendency in the behavior of that variable was observed.

The analysis of the relation between in-hospital mortality and the other variables studied revealed greater rates among females and the elderly. In the acute group, the presence of diabetes mellitus as an associated diagnosis related to a greater in-hospital mortality. However, when considered together in the multiple logistic regression model, only the variables sex and age for the acute group and age for the chronic group had an association with greater in-hospital mortality rates.

Greater in-hospital mortality rates due to myocardial infarction have already been reported in female patients, in the elderly, and in diabetic patients ${ }^{7-10,24}$. In our study, sex and age were associated with greater coefficients of inhospital mortality in multivariate analysis. However, the greater influence of age (odds ratio $=1.016$ ) suggested that, at least partially, the greater in-hospital mortality rate in females may be explained by the fact that these patients are older ${ }^{25,26}$. The diabetes mellitus variable was not statistically significant in the multivariate analysis, suggesting that the increase in mortality among diabetic patients may be secondary to an increase in the percentage of older patients, among whom the disease is more prevalent.

In conclusion, all these findings point to a change in the profile of the population with ischemic heart disease admitted to InCor during the period studied, indicating a poorer prognosis associated with greater morbidity and mortality rates. This suggests that in the final decade of the 20 th century, the patients became older, more females were affected, and the prevalence of diabetes mellitus increased.

Our study also confirms the findings of previous studies regarding the greater in-hospital mortality due to ischemic heart disease in females, in the elderly, and in patients with diabetes mellitus as an associated disease. Despite these results, no change in in-hospital mortality was observed during the study period. The recent advances in treatment and prevention of ischemic heart disease may have somehow compensated for the changes in the patients' characteristics.

\section{References}

1. Avezum, A. Cardiologia baseada em evidências e avaliação crítica da literatura cardiológica: princípios de epidemiologia clínica aplicados à cardiologia. Rev Soc Cardiol Estado de São Paulo 1996; 6: 241-59.

2. The University Of Chicago. Population. In: Enciclopedia Britannica. $15^{\text {a. ed. }}$ Chicago: Encyclopedia Britannica, Inc, 1991; 25: 1034-43.

3. LeserW, Barbosa V, Baruzzi RG, Ribeiro MBD, Franco LJ. Elementos de Epidemiologia Geral. Rio de Janeiro/São Paulo: Livraria Atheneu, 1988. 177p.

4. Lotufo PA, Lolio CA. Tendência da mortalidade por doença isquêmica do coração no Estado de São Paulo: 1970 a 1989. Arq Bras Cardiol 1993; 61:149-53.

5. Naylor CD, Chen E. Population-wide mortality trends among patients hospitalized for acute myocardial infarction: the Ontario experience, 1981 to 1991. J Am Coll Cardiol 1994; 24:1431-8.

6. Gillum RF. Trends in acute myocardial infarction and coronary heart disease death in the United States. Am J Cardiol 1994; 23: 1273-7.

7. ISIS-2 (Second International Study Of Infarction Survival) Collaborative Group: Randomised trial of intravenous streptokinase, oral aspirin, both, or neither among 17,187 cases of suspected acutemyocardial infarction: ISIS-2. Lancet 1988; II: 349-60.

8. Gruppo Italiano Per Lo Studio Della Streptochinasi Nell' Infarto Miocardico (GISSI): Effectiveness of intravenous thrombolytic treatment in acute myocardial infarction. Lancet 1986; I: 397-401.

9. Zuanetti G, Latini R, Maggioni AP, Santoro L, Franzosi MG. Influence of diabetes on mortality in acute myocardial infarction: data from the GISSI-2 study. JAm Coll Cardiol 1993; 22: 1788-94.

10. Jacoby RM, Nesto RW. Acute myocardial infarction in the diabetic patient: pathophysiology, clinical course and prognosis. JAm Coll Cardiol 1992; 20: 736-44.

11. Diegues RCDP, Novaes Rl, Zabala R, et al. Demografia e procedimentos no infarto agudo do miocárdio: estudo comparativo entre diferentes períodos. (Abstract). Arq Bras Cardiol 1996; 67(suppl I): 98.

12. Pepine CJ, Abrams J, Marks RG, Morris JJ, ScheidtSS, Handberg E. Characteristics of a contemporary population with angina pectoris. Am J Cardiol 1994; 74: 226-31.

13. Giacomini MK. Gender and ethnic differences in hospital-based procedure utilization in California. Arch Intern Med 1996; 156: 1217-24.

14. Ministério da Saúde. Coordenação de Doenças Cardiovasculares. Doenças Cardiovasculares no Brasil. Sistema Único de Saúde - SUS. Brasília, 1993. 36p.

15. Chor D, Fonseca MJM, Andrade CR. Doenças cardiovasculares: comentários sobre a mortalidade precoce no Brasil. Arq Bras Cardiol 1995; 64: 15-9.

16. Tunstall-Pedoe H, Kuulasmaa K, Amouyel P, Arveiler D, Rajakangas A, Pajak A. Myocardial infarction and coronary deaths in the World Health Organization MONICA Project. Circulation 1994; 90: 583-612.

17. Friesinger GC. The natural history of atherosclerotic coronary heart disease. In: Schlant RC, Alexander W. ed. Hurst's The Heart:Arteries and Veins. New York: McGraw-Hill, Inc, 1994; 1185-203.

18. Fisher LD, Kronmal RA, Davis KB, et al. Coronary artery surgery study (CASS): a randomized trial of coronary artery bypass surgery survival data. Circulation 1983; 68: 939-50.

19. Organização Mundial da Saúde (CID-10). Classificação Estatística Internacional de Doenças e Problemas Relacionados à Saúde. $10^{\circ}$ revisão. São Paulo: EDUSP, 1996. 1191p.

20. Rosner B. Fundamentals of Biostatistics. Boston: PWS Publishers, 1986.

21. Hosmer DW, Lemeshow S. Applied Logistic Regression. New York: John Wiley \& Sons, 19.

22. Roberts R, Morris D, Pratt CM, Alexander RW. Pathophysiology recognition and treatment of acute myocardial infarction and its complications. In: Schlant, 
R.C.; Alexander, W. ed. Hurst's The Heart: Arteries and Veins. New York: McGraw-Hill, Inc, 1994, p. 1107-1185.

23. Davidsen M,Bronnum-Hansen H,GerdesLU.Developmentofmyocardial infarctionin the Glostrup area, Denmark from 1982 to 1992. Can JCardiol 1997; 13 (supplB): 154.

24. Jánosi A, Ofner P, Winkler G. Epidemiological data on myocardial infarction and diabetes mellitus. Can J Cardiol 1997; 13 (suppl B): 200.
25. Jakobsen TJ, Torp-Pedersen C, Hildebrandt P, et al. Difference in survival following acute myocardial infarction between men and women is due to age. Can J Cardiol 1997; 13 (suppl B): 52B.

26. Pankow JS, Mcgovern PG, Shahar E, Doliszny KM, Luepker RV. Is short-term mortality from acute coronary heart disease higher in women than men? Can J Cardiol 1997; 13 (suppl B): 57B.

Bula resumida - MICARDIS $\circledast$ Telmisartam - Uso adulto - Forma farmacêutica e apresentações: Comprimidos de $40 \mathrm{mg}$ : embalagens com 14 e 28 comprimidos. Comprimidos de $80 \mathrm{mg}$ : embalagens com 14 e 28 comprimidos. Composição: Cada comprimido contém $40 \mathrm{mg}$ ou $80 \mathrm{mg}$ de telmisartam. Exçipientes q.s.p. 1 comprimido. Indicações: Tratamento da hipertensão arterial, como monoterapia ou em associação com outros agentes anti-hipertensivos. Contra-indicações: Hipersensibilidade ao ingrediente ativo ou aos excipientes. Gravidez e lactação. Obstrução biliar. Disfunção hepática ou renal grave. Intolerância hereditária à frutose. Precauções: Hipertensão renovascular: pacientes com estenose arterial renal bilateral ou estenose da artéria com um único rim funcionando: risco aumentado de hipotensão grave e insuficiência renal. Disfunção renal ou transplante hepático: monitoração periódica dos niveis séricos de potássio e creatinina. Não há experiência em pacientes com transplante renal recente. Desidratação: hipotensão sintomática, especialmente após a primeira dose, pode ocorrer em pacientes que têm volemia e/ou sódio depletado, o que deve ser corrigido antes do início da terapêutica com MICARDIS. Outras condições de estimulação do SRAA e condiçỗes dependentes da atividade SRAA (insuficiência cardíaca congestiva grave): hipotensão aguda, hiperazotemia, oligúria ou, raramente, insuficiência renal aguda. Hiperaldosteronismo primário: não se recomenda o uso de MICARDIS. Estenose valvar aórtica e mitral e cardiomiopatia hipertrófica obstrutiva: Recomenda-se precaução especial. Hipercalemia: recomendase monitoração adequada dos niveis séricos de potássio em pacientes de risco. Diuréticos poupadores de potássio, suplementos de potássio, sais de potássio ou outros medicamentos que podem aumentar os níveis de potássio, como a heparina: podem levar a um aumento da potassemia. Portanto, nestas situações MICARDIS deve ser administrado com cautela. Distúrbios hepatobiliares: pode-se esperar redução da depuração em pacientes com disfunções obstrutivas do sistema biliar ou insuficiência hepática, pois a eliminação da droga é principalmente biliar. Intolerância à frutose: os comprimidos de MICARDIS contém sorbitol; portanto, é inadequado para pacientes com intolerância hereditária à frutose. Outros: menor eficácia na redução da pressão arterial na população negra do que na população não-negra. Cardiopatia isquêmica ou doença cardiovascular isquêmica pode resultar em infarto do miocárdio. Interações medicamentosas: MICARDIS pode aumentar o efeito hipotensor de outros agentes anti-hipertensivos. Observouse um aumento de $20 \%$ da concentração plasmática média de digoxina. Relataram-se aumentos reversiveis das concentrações séricas de lítio e de toxicidade; portanto, recomenda-se cuidadosa monitoração
do uso concomitante com lítio. Gravidez e lactação: Contra-indicado. Reações adversas: As reações adversas à droga obtidas a partir de todos os estudos clínicos com telmisartam foram: Infecções do trato urinário, infecções do trato respiratório superior, ansiedade, visão anormal, vertigem, dor abdominal, diarréia, boca seca, dispepsia, flatulência, dor de estômago, eczema, aumento de suor, artralgia, dor nas costas, cãibras nas pernas ou dores nas pernas, mialgia, sintomas de tendinite, dor no peito, sintomas de gripe. Além disso, desde a introdução de telmisartam no mercado, relataram-se casos raros de eritema, prurido, desmaio, insônia, depressão, vômito, hipotensão, bradicardia, taquicardia, dispnéia, eosinofilia, trombocitopenia, fraqueza e perda de eficácia. Relataram-se casos isolados de angioedema, urticária e outros eventos relacionados. Investigações: Raramente, observaram-se diminuição na hemoglobina ou aumento no ácido úrico. Observaram-se aumentos na creatinina ou nas enzimas hepáticas. Efeitos na habilidade de dirigir e utilizar máquinas: Ainda não se realizaram estudos específicos. Contudo, ao dirigir ou operar máquinas, pode ocasionalmente ocorrer tontura ou sonolência. Posologia: A dose
recomendada é de $40 \mathrm{mg}$ uma vez ao dia. Alguns pacientes podem apresentar benefício com dose diária de $20 \mathrm{mg}$. Em casos em que a pressão arterial pretendida não seja atingida, a dose de MICARDIS pode ser aumentada para no máximo $80 \mathrm{mg}$ uma vez ao dia. Alternativamente, MICARDIS pode ser usado em combinação com diuréticos tiazídicos, como a hidroclorotiazida, para se obter uma redução maior da pressão arterial. Quando se considerar um aumento da dose, deve-se levar em conta que o máximo efeito anti-hipertensivo é geralmente atingido quatro a oito semanas após o início do tratamento. MICARDIS pode ser administrado com ou sem alimento. Insuficiência renal: Não há necessidade de ajustes de dose em pacientes com insuficiência renal leve a moderada. Telmisartam não é removido do sangue por Crianças e adolescentes: Não há dados de segurança e eficácia de MICARDIS em crianças e adolescentes. VENDA SOB PRESCRIÇÃO MÉDICA - MS - 1.0367.0110 - Boehringer Ingelheim do Brasil Química e Farmacêutica Ltda.

Bula resumida - MICARDIS ${ }^{\circledast}$ HCT - Telmisartam/Hidroclorotiazida - Uso adulto - Composição: Cada comprimido de MICARDIS HCT contém $40 \mathrm{mg} / 12,5 \mathrm{mg}$ ou $80 \mathrm{mg} / 12,5 \mathrm{mg}$ de telmisartam/hidroclorotiazida. Embalagens com 14 e 28 comprimidos. Excipientes q.s.p. 1 comprimido. Indicações: Tratamento da hipertensão arterial. MICARDIS HCT, como associação de dose fixa, é indicado em pacientes cuja pressão arterial não é adequadamente controlada com telmisartam ou hidroclorotiazida isoladamente. Posologia: MICARDIS HCT deve ser administrado uma vez ao dia. A dose de MICARDIS pode ser aumentada gradativamente antes de substituí-Io pelo MICARDIS HCT. A substituição direta da monoterapia pelas combinações fixas pode ser considerada. MICARDIS HCT 40/12,5 mg pode ser administrado em pacientes cujas pressões sangüineas não sejam adequadamente controladas por MICARDIS $40 \mathrm{mg}$ ou hidroclorotiazida. MICARDIS HCT 80/12,5 mg pode ser administrado em pacientes cujas pressões arteriais não sejam adequadamente controladas por MICARDIS $80 \mathrm{mg}$ ou por MICARDIS HCT 40/12,5 mg. 0 máximo efeito anti-hipertensivo é obtido após 4 a 8 semanas de tratamento. Quando necessário, MICARDIS HCT pode ser administrado com outros anti-hipertensivos. MICARDIS HCT pode ser administrado com ou sem alimento. Devido ao componente hidroclorotiazida, MICARDIS HCT não deve ser usado em pacientes com isfunçâo renal grave. Nos casos leves a moderados, não se observaram efeitos adversos renais e não é necessário ajuste de dose. Recomenda-se monitoração periódica da função renal. Nos casos de de dose conforme a idade. Ainda não se estabeleceram a segurança e a eficácia de MICARDIS HCT em pacientes menores de 18 anos. Contra-indicações: Hipersensibilidade aos componentes ativos, excipientes ou substâncias derivadas de sulfonamidas (como HCT). Gravidez e lactação. Colestase e distúrbios obstrutivos biliares. Insuficiência hepática ou renal grave (depuração de creatinina <30 ml/min). Hipopotassemia refrataria e hipercalcemia. Precauçōes: Não utilizar nos casos de colestase, distưrbios biliares obstrutivos ou insuficiência hepatica grave. Usar com cautela nos casos de função hepática alterada ou doença hepática progressiva, pois pode ocorrer coma hepático. Há maior risco em pacientes com estenose arterial renal bilateral ou estenose com um único rim funcionando. Micardis HCT não deve ser administrado em pacientes portadores de disfunção renal grave. Não há experiência quanto à administração de MICARDIS HCT em pacientes com grave insuficiência renal ou com um rim transplantado recentemente. Recomenda-se a monitoração periódica dos niveis séricos de potássio, creatinina e ácido úrico. A azotemia associada a diuréticos tiazidicos pode ocorrer em pacientes com função renal alterada. Pode ocorrer hipotensão sintomática em pacientes que têm volemia e/ou sódio depletado. Insuficiência cardíaca congestiva grave ou doença renal, estenose da artéria renal tratada concomitantemente com drogas que afetem o sistema renina-angiotensina-aldosterona foram associados com hipotensão aguda, hiperazotemia, oligúria ou, raramente, insuficiência renal aguda. Aldosteronismo primário: não se recomenda o uso de telmisartam, precaução especial em estenose valvar aórtica ou mitral e cardiomiopatia hipertrófica obstrutiva. Como tiazidas podem prejudicar a tolerância à glicose, pode ser necessário ajuste no tratamento em diabéticos e pode ocorrer manifestação de diabetes latente. A hidroclorotiazida aumenta os niveis de colesterol e triglicérides; contudo, nenhum ou poucos efeitos adversos foram relatados na dose de $12,5 \mathrm{mg}$ contida em MICARDIS HCT. Pode ocorrer hiperuricemia ou precipitação de gota devido a hidroclorotiazida. Pode ser necessária monitoração periódica dos níveis séricos de reduzir a diuréticos, devido aos efeitos antagônicos. Diuréticos poupadores de potássio, suplementos de potássio ou substitutos do sal contendo potássio devem ser utilizados dos niveis séricos de cálcio e manésio. Interromper o uso antes dos testes re função previna hiponatremia induzida por diuréticos. A déficiência de cloreto e geralmente leve. Tiazidas podem causar elevação cardiovascular isquêmica pode ser prejudicial. Relatou-se exacerbação ou ativação do lupus eritematoso sistêmico com o uso de hidroclorotiazida. Recomenda-se cautela no uso de anti-hipertensivos ao dirigir e operar máquinas. Interações medicamentosas: Relataram-se aumentos reversíveis das concentrações séricas de lítio durante administração concomitante com inibidores da enzima conversora de e operar maquinas. Interaçôes medicamentosas: Relataram-se aumentos reversiveis das concentraçoes sericas de litio durante administração concomitante com inibidores da enzima conversora de dos niveis séricos de lítio durante 0 uso concomitante. 0 efeito de depleção de potássio da hidroclorotiazida é atenuado pelo efeito poupador de potássio do telmisartam, mas é potencializado por outros diuréticos caliuréticos, caliuréticos, laxantes, corticosteróides, ACTH, anfotericina, carbenoxolona, penicilina G sódica, ácido salicílico e derivados. Por outro lado, o uso concomitante de diuréticos poupadores de potássio, suplementos/sais de potássio ou outras drogas podem aumentar os niveis séricos de potássio. Nesses casos, recomenda-se a monitoração dos niveis plasmáticos de potassio. Recomenda-se monitoração pertro outros agentes anti-hipertensivos. Observou-se um aumento de $20 \%$ da concentração plasmática média de digoxina. Náo se identificaram outras interaçóes de importância clínica. Interaçôes com a hidroclorotiazida: álcool, barbitúricos ou narcóticos (potencialização da hipotensão ortostática); drogas antidiabéticas (ajustes de dose podem ser necessários); metformina (risco de acidose láctica);
colestiramina e resina colestipol (absorção de hidroclorotiazida é prejudicada); corticosteróides. ACTH (deplecão eletrolítica, principalmente aumento de hipopotassemia); glicosídeos digitálicos (hipopotassemia ou hipomagnesemia induzida por tiazídicos favorece o aparecimento de arritmias cardíacas induzidas por digitálicos); drogas antiinflamatórias não-esteroidais (a administração de droga antiinflamatória não-esteroidal pode reduzir o efeito diurético, natriurético e anti-hipertensivo dos diuréticos tiazídicos em alguns pacientes). Os efeitos das aminas hipertensoras podem ser levemente diminuídos. 0s relaxantes musculares esqueléticos não-despolarizantes são potencializados pela hidroclorotiazida. Medicamentos uricosúricos podem requerer ajustes. Verificou-se aumento da incidência de reações de hipersensibilidade ao alopurinol. Os efeitos hiperglicêmicos dos beta-bloqueadores e diazóxido podem ser aumentados pelas tiazidas. Os agentes anticolinérgicos (por exemplo, atropina, biperideno) podem aumentar a biodisponibilidade das tiazidas. As tiazidas podem aumentar os eventos adversos da amantadina. As tiazidas podem reduzir a excreção renal de drogas citotóxicas (por exemplo, ciclofosfamida, metotrexato). Gravidez e lactação: É contra-indicado. Se ocorrer gravidez, telmisartam deve ser descontinuado o mais breve possível. As tiazidas atravessam a barreira placentária e podem causar distúrbios eletrolíticos no feto e é possivel que ocorram outras reações. Relataram-se casos de trombocitopenia ou icterícia neonatal com o tratamento tiazídico materno. Tiazidas são excretadas no leite humano e podem inibir a lactação. Reações adversas: Foram relatadas as seguintes reações adversas: Bronquite, faringite, sinusite, infecções do trato respiratório superior, infecções do trato urinário, sialadenite, eosinofilia, anemia aplástica, anemia hemolítica, depressão da medula óssea, leucopenia, neutropenia/agranulocitose, trombocitopenia, alergia, reações anafiláticas, perda do controle da diabete, hipercolesterolemia, hiperuricemia, hipopotassemia, causa ou aumento da depleção de volume, desequilíbrio eletrolítico, hiponatremia, anorexia, perda de apetite, hiperglicemia, ansiedade, depressão, inquietação, tontura, desmaio, insônia, escotomas, parestesia, distúrbios do sono, visão alterada, visão borrada temporariamente, xantopsia, vertigem, bradicardia, taquicardia, arritmias cardíacas, hipotensão, hipotensão postural, angiite necrotizante (vasculite), dispnéia, sofrimento respiratório (incluindo pneumonite e edema pulmonar), dor abdominal, diarréia, dispepsia, gastrite, dor de estômago, boca seca, flatulência, vômito, constipação, pancreatite, icterícia (icterícia hepatocelular ou colestática), eczema, aumento do suor, eritema, prurido, reações cutâneas do tipo lupus eritematoso, vasculite cutânea, reações de fotossensibilidade, erupções cutâneas, reativação do lupus eritematoso cutâneo, necrólise epidérmica tóxica, atralgia, artrose, dor nas costas, dor nas pernas, mialgia, cãibras nas pernas, sintomas de tendinite, fraqueza, espasmo muscular, nefrite intersticial, disfunção renal, glicosúria, impotência, sintomas de gripe, dor, dor no peito, perda da eficácia, febre. Investigações: Diminuição da hemoglobina, aumento do ácido úrico, aumento na creatinina, aumento das enzimas hepáticas, aumento dos triglicérides. Assim como ocorre com outros antagonistas da angiotensina II, relataram-se casos isolados de angioedema, urticária e outras reações relacionadas. VENDA SOB PRESCRIÇÃO MÉDICA. - MS 1.0367.0134 Boehringer Ingelheim do Brasil Química e Farmacêutica Ltda. 